\title{
Evaluation Of Code Blue Calls Pre-Pandemic And Post-Pandemic Period In A State Hospital: Single Center Experience
}

\section{Bir Devlet Hastanesinde Mavi Kod Çağrılarının Pandemi Öncesi ve Pandemi Sonrası Dönemde Değerlendirilmesi: Tek Merkez Deneyimi}

\author{
Metin OCAK ${ }^{1} \mathbb{D}$, Mustafa Beğenç TAŞCANOV 2 (D) \\ ${ }^{1}$ Gazi State Hospital, Emergency Clinic, Samsun,TURKEY \\ 2 Department of Cardiology, Harran University Faculty of Medicine, Sanliurfa,TURKEY
}

Background: Code blue is an organization established to provide basic and advanced life support as soon as possible, effectively and accurately in patients who develop in-hospital cardiac arrest. The aim of this study is to investigate the effectiveness and results of code blue calls (CBCs) in our hospital, to make a comparison between pre-pandemic and post-pandemic periods, and to contribute to the literature and clinical practice. Materials and Methods: This study was carried out by retrospectively examining the code blue notification forms between 01.01.2019 and 20.05.2021 in the code blue system, which is actively applied in the 350-bed Samsun Gazi State Hospital.

Results: 370 code blue calls were included in this retrospective study. $54.1 \%$ of the cases were male and the mean age was $63.6 \pm 1.1$ years. $55.7 \%$ of the calls were made during working hours. The calls were mostly made from polyclinics with $28.6 \%$. This was followed by the Covid-19 service with $25.7 \%$ and the palliative care service with $15.9 \%$. $60 \%$ of the calls were made in the pre-pandemic period. CPR was performed in $48.6 \%$ of the cases. $30.3 \%$ of the cases resulted in exitus. In terms of CBC causes, code blue call was made due to cardiopulmonary arrest in $48.6 \%$, syncope in $16.8 \%$, and hypotensive attack in $13 \%$ of the cases. Code Blue team reached the calls in an average of $2.63 \pm 0.1$ minutes. When $\mathrm{CBCs}$ during the pandemic period were compared with the pre-pandemic period; age, male gender ratio, transfer rate to the ICU, team response time and prolenged call rates were found to be higher during the pandemic period ( respectively $p=0.017$, $p=0.03, p=0.001, p=0.001, p=0.006$ ) . The defibrillation rate and the rate of transfer to the ED were found to be lower during the pandemic period (respectively $p=0.02, p=0.001$ ).

Conclusions: When pandemic period and pre-pandemic period of CBCs in our hospital were compared; it was found that parameters such as defibrillation application, outcome, team arrival time and prolonged call rates were negatively affected. $\mathrm{CBC}$ and its results can be improved with continuous and effective training.

Key Words: Code Blue, Cardiopulmonary Resuscitation, In-Hospital Cardiopulmonary Arrest, Pandemic, Code Blue Training

Öz.

Amaç: Mavi Kod Hastane içi kardiyak arrest gelişen hastalarda temel ve ileri yaşam desteğini en kısa sürede, etkin ve doğru bir şekilde yapmak için oluşturulmuş organizasyondur. Bu çalışmada amacımız hastanemizdeki mavi kod çağrılarının (MKÇ) etkinliği ve sonuçlarını araştırmak ve pandemi öncesi-pandemi sonrası karşılaştırılmasını yapmak, literatüre ve uygulamaya katkı sağlamaktır.

Materyal ve Metod: çalışma 350 yataklı Samsun Gazi Devlet Hastanesi'nde aktif olarak uygulanmakta olan mavi kod sisteminde 01.01.2019-20.05.2021 tarihleri arasındaki mavi kod bildirim formlarının retrospektif olarak incelenmesi ile yapılmıştır.

Bulgular: Bu retrospektif çalışmaya 370 mavi kod çağrısı dahil edilmiştir. Vakaların \% 54.1'i erkek olup ortalama yaş $63.6 \pm 1.1$ yıl idi. Çağrıların \%55.7'si mesai içinde verilmiştir. Çağrılar en sık \%28.6 ile polikliniklerden verilmiştir. Bunu \%25.7 ile pandemi servisi ve \%15.9 palyatif bakım servisi izlemektedir. Çağrıların\%60'ı pandemi öncesi dönemde verilmiştir. Vakaların \%48.6'sına CPR yapılmıştır. Vakaların \%30.3'ü exitus ile sonuçlanmıştır. MKÇ'nin verilme sebeplerine baktığımızda; \%48.6 hastaya kardiyopulmoner arrest, \%16.8 hastaya senkop, \%13 hastaya ise hipotansif atak nedeniyle mavi kod çağrısı verilmiştir. Mavi kod ekibi çağrılara ortalama $2.63 \pm 0.1$ dakikada ulaşmıştır. Pandemi dönemi ile pandemi öncesi dönemdeki MKÇ'ler karşılaştırıldığında; pandemi döneminde yaş, erkek cinsiyet oranı, YB'a transfer oranı, ekip yanıt süresi ve uzayan çağrı oranları daha yüksek bulundu (sırasıyla $p=0.017 ; p=0.03 ; p=0.001 ; p=0.001 ; p=0.006$ ). Pandemi döneminde defibrilasyon hızı ve AS'e transfer hızı daha düşük bulundu (sırasıyla $p=0.02 ; p=0.001$ ).

Sonuç: Hastanemizdeki MKÇ’lerde pandemi dönemi ile pandemi öncesi dönem karşılaştırıldığında; defibrilasyon uygulama, sonuç, ekip geliş süresi ve uzamış çağıı oranları gibi parametrelerin negatif yönde etkilendiği bulundu. MKÇ sonuçları sürekli ve etkili eğitimlerle daha iyi seviyelere çıkarılabilir.

Anahtar kelimeler: Mavi Kod, Kardiyopulmoner Resusitasyon, Hastane İçi Kardiyapulmoner Arrest, Pandemi, Mavi Kod Eğitimi
Corresponding Author / Sorumlu Yazar

Dr. Metin OCAK

Gazi State Hospital,

Emergency Clinic

55100 Samsun, TURKEY

E-mail: mdmocak@gmail.com

Received / Geliş tarihi: 14.08.2021

Accepted / Kabul tarihi: 09.11.2021

DOI: 10.35440/hutfd.982983 


\section{Introduction}

Code blue as an organization-based system for initiating, performing and terminating, within a professional team, the intervention of patients who develop respiratory and cardiac arrest in hospitals (1). In other words, it is an organization established to provide basic and advanced life support as soon as possible, effectively and accurately in patients who develop in-hospital cardiac arrest (IHCA) $(2,3)$. Code blue is the only color code in the world where the same color is used for an emergency (1). Code blue system was first used in the USA, and it started to be used in Turkey in 2008 (4). After an official communiqué made by the Ministry of Health in 2009 and the "Patient and Employee Safety Regulation" published in 2011, its implementation in hospitals has become mandatory (5). Code blue team consists of a doctor, nurse, anesthesia technician, careworker, and security guard (5).

It is known that patients with out-of-hospital cardiac arrest have a poor prognosis (6). However, IHCA continues to be an important problem worldwide (7). According to previous studies, the incidence of IHCA in the United States (USA) is reported to be around 9-10/1000. In addition, despite all the developments in the field of cardiopulmonary resuscitation (CPR) and improvements in post-arrest care, the rate of discharge after IHCA remains around $20-30 \%(8,9)$. Although the cause of IHCA is usually an underlying disease, delayed, incorrect and inadequate CPR increases the mortality of patients (10). In a previous study, it was reported that false resuscitation was applied to $40 \%$ of patients with ventricular fibrillation/pulseless ventricular tachycardia (11).

Coronavirus disease 2019 (COVID-19) emerged in China towards the end of 2019 and the World Health Organization declared it a pandemic on March 11, 2020 (12). After the pandemic, there have been many changes in the health system and hospitals in Turkey as well as all over the world. For example, elective surgery cases and hospitalizations were stopped in our country, and many services and intensive care areas were reserved for COVID-19 patients. In addition, patient applications to the hospital have decreased due to concerns of COVID-19 infection.

The aim of this study is to investigate the effectiveness and results of code blue calls (CBCs) in our hospital, to make a comparison between pre-pandemic and post-pandemic periods, and to contribute to the literature and clinical practice.

There are many studies in the literature examining CBCs and its results (1-4). However, to the best of our knowledge, this is the first study to compare the effectiveness and application results of $\mathrm{CBCs}$ before and after the pandemic.

\section{Materials and Methods}

This study was carried out by retrospectively examining the code blue notification forms between 01.01.2019 and
20.05.2021 in the code blue system, which is actively applied in the 350-bed Samsun Gazi State Hospital. With March 112020 taken as the beginning of the pandemic, the study period was the same before and after the pandemic. Ethical permission for the study was obtained by the decision of the Health Sciences University Samsun Training and Research Hospital Non-Interventional Clinical Research Ethics Committee dated 05.05.2021 and numbered 2021/9/13.

In our hospital, the call system works with the activation of the call number 2222. In our hospital, code blue team leaders consist of anesthesiologists and internists. Code blue notification forms are filled in regularly by the team and delivered to the quality unit of our hospital.

Anesthesiologists and emergency medicine specialists are available 24 hours a day in the intensive care units (ICU) and the emergency department (ED) of our hospital. Therefore, $\mathrm{CBCs}$ are not made from these units. Calls inadvertently made from these units were excluded from the study. In code blue notification forms, information such as age, gender, service or unit of the patients, the diagnosis at hospitalization if the patient is an inpatient, the reason for code blue, date, time, time of arrival of the code blue team to the scene, interventions performed on the patient, whether CPR was performed, CPR result, and the drugs used during CPR can be accessed. Calls with missing or unclear information on the code blue notification forms were excluded from the study. In addition, CBCs made by mistake and for practice purposes were not included in the study.

\section{Statistical analysis}

Statistical Program for Social Sciences 20 (IBM SPSS, Chicago, IL, USA) was used for all statistical calculations. Kolmogorov-Smirnov test was used to check whether the data were normally distributed. Continuous variables were expressed as mean \pm SD or median (interquartile range) and compared with Student's t or Mann-Whitney $U$ tests according to normality. Categorical variables were expressed as percentages and numbers and compared with the Chisquare test. A value of $p<0.05$ was considered statistically significant.

\section{Results}

370 code blue calls were included in this retrospective study. $54.1 \%$ of the cases were male and the mean age was $63.6 \pm 1.1$ years. $55.7 \%$ of the calls were made during working hours. The calls were mostly made from polyclinics with $28.6 \%$. This was followed by the Covid-19 service with $25.7 \%$ and the palliative care service with $15.9 \%$. For the eligibility of code blue calls, $51.4 \%$ of the calls were inappropriate based on patients in need of basic and advanced cardiopulmonary life support. $60 \%$ of the calls were made in the pre-pandemic period. CPR was performed in $48.6 \%$ of the cases. $30.3 \%$ of the cases resulted in exitus. $36.2 \%$ of 
cases were transferred to the ED for treatment and observation. Demographic and general characteristics of CBCs are shown in Table 1.

Table 1. Demographic and general characteristics of CBCs

\begin{tabular}{|c|c|}
\hline & $n=370$ \\
\hline Age, years & $63.6 \pm 1.1$ \\
\hline \multicolumn{2}{|l|}{ Gender } \\
\hline Female (\%) & $170(45.9)$ \\
\hline Male (\%) & $200(54.1)$ \\
\hline \multicolumn{2}{|l|}{ Working Status } \\
\hline Overtime (\%) & $206(55.7)$ \\
\hline Non-Overtime (\%) & $164(44.3)$ \\
\hline \multicolumn{2}{|l|}{ Call Place } \\
\hline Polyclinics (\%) & $106(28.6)$ \\
\hline Pandemic Service (\%) & $95(25.7)$ \\
\hline Palliative Care Service (\%) & $59(15.9)$ \\
\hline Radiology/Imaging (\%) & $16(4.3)$ \\
\hline Laboratory (\%) & $10(2.7)$ \\
\hline Dialysis Unit (\%) & $4(1.1)$ \\
\hline Internal Medicine Service (\%) & $25(6.8)$ \\
\hline Infectious Diseases Service (\%) & $12(3.2)$ \\
\hline Orthopedic Service (\%) & $9(2.4)$ \\
\hline General Surgery Service (\%) & $12(3.2)$ \\
\hline Neurology Service (\%) & $16(4.3)$ \\
\hline Cardiology Service (\%) & $3(0.8)$ \\
\hline Urology Service (\%) & $1(0.3)$ \\
\hline Neurosurgery Service (\%) & $1(0.3)$ \\
\hline Chest Diseases Service (\%) & $1(0.3)$ \\
\hline \multicolumn{2}{|l|}{ Call Suitability } \\
\hline Appropriate Call (\%) & $180(48.6)$ \\
\hline Inappropriate Call (\%) & $190(51.4)$ \\
\hline \multicolumn{2}{|l|}{ Pandemic Status } \\
\hline Before Pandemic (\%) & $222(60)$ \\
\hline Pandemic Period (\%) & $148(40)$ \\
\hline \multicolumn{2}{|l|}{ Treatment Performed } \\
\hline $\mathrm{CPR}^{*}(\%)$ & $180(48.6)$ \\
\hline Vascular Insertion + Fluid Therapy (\%) & $261(70.5)$ \\
\hline Endotracheal Intubation (\%) & $174(47)$ \\
\hline $\mathrm{IV}^{* *}$ adrenaline (\%) & $181(48.9)$ \\
\hline IV atropine (\%) & $32(8.6)$ \\
\hline Defibrillation (\%) & $7(1.9)$ \\
\hline \multicolumn{2}{|l|}{ Result } \\
\hline Exitus (\%) & $112(30.3)$ \\
\hline Transfer to Intensive Care Unit (\%) & $88(23.8)$ \\
\hline Transfer to Emergency Room (\%) & $134(36.2)$ \\
\hline Follow-up in the Inpatient Service (\%) & $36(9.7)$ \\
\hline Total $(\%)$ & $370(100)$ \\
\hline
\end{tabular}

${ }^{*}$ CPR: Cardiopulmonary Resuscitation; ${ }^{* *} I V$ : Intravenous

In terms of $\mathrm{CBC}$ causes, code blue call was made due to cardiopulmonary arrest in $48.6 \%$, syncope in $16.8 \%$, and hypotensive attack in $13 \%$ of the cases. When the hospitalization diagnosis of the inpatients were examined, it was seen that
$39.5 \%$ of the diagnoses were COVID-19, $22.7 \%$ were malignancy, and $9 \%$ were cerebrovascular event (CVE). Causes of $\mathrm{CBCs}$ in our study and the hospitalization diagnoses of the patients are shown in Table 2.

Table 2. Causes of Cbcs and The Hospitalization Diagnoses of The Patients

\begin{tabular}{|l|c|}
\hline Reason for Call & $\mathbf{n = 3 7 0}$ \\
\hline Cardiopulmonary Arrest (\%) & $180(48.6)$ \\
\hline Syncope (\%) & $62(16.8)$ \\
\hline Seizure (\%) & $15(4.1)$ \\
\hline Anxiety/Conversion (\%) & $19(5.1)$ \\
\hline Hypotensive Attack (\%) & $48(13)$ \\
\hline Consciousness Change (\%) & $7(1.9)$ \\
\hline General Condition Disorder (\%) & $31(8.4)$ \\
\hline Chest Pain (\%) & $1(0.3)$ \\
\hline Anaphylaxis (\%) & $2(0.5)$ \\
\hline Respiratory Distress (\%) & $3(0.8)$ \\
\hline Arrhythmia (\%) & $2(0.5)$ \\
\hline Total (\%) & $370(100)$ \\
\hline Diagnosis of Inpatients Called & $\mathbf{n = 2 3 3}$ \\
\hline COVID-19 (\%) & $92(39.5)$ \\
\hline Malignancy (\%) & $53(22.7)$ \\
\hline Cerebrovascular Event (\%) & $21(9)$ \\
\hline Acute Kidney Failure (\%) & $4(1,7)$ \\
\hline Chronic renal failure (\%) & $8(3.4)$ \\
\hline Hypertension (\%) & $3(1.3)$ \\
\hline Diabetes Mellitus (\%) & $4(1.7)$ \\
\hline Congestive Heart Failure (\%) & $5(2.2)$ \\
\hline Orthopedic Surgery (\%) & $9(3.9)$ \\
\hline Epilepsy (\%) & $2(0.9)$ \\
\hline Pneumonia (\%) & $8(3.4)$ \\
\hline Sepsis (\%) & $7(3)$ \\
\hline Urinary System Infection (\%) & $4(1.7)$ \\
\hline Acute Appendicitis (\%) & $2(0.9)$ \\
\hline Pulmonary Thromboembolism (\%) & $1(0.4)$ \\
\hline Chronic Obstructive Pulmonary Disease & $3(1.3)$ \\
\hline (\%) & $4(1.7)$ \\
\hline ileus (\%) & $2(0.9)$ \\
\hline Gastroenteritis (\%) & $1(0.4)$ \\
\hline Nephrolithiasis (\%) & $233(100)$ \\
\hline Total (\%) & \\
\hline & \\
\hline
\end{tabular}

$17.8 \%$ of the CBCs were made between 10 a.m and 12 p.m, $12.7 \%$ were made between 12 p.m and 14 p.m. $9.7 \%$ of the calls were made in December 2020, 6.2\% in March 2019, and $6.2 \%$ were made in June 2019. The distribution of CBCs by hours and months is shown in Figure 1 and Figure 2. Code Blue team reached the calls in an average of $2.63 \pm 0.1$ minutes. Based on $\leq 3$ minutes, the code blue team arrived late to $3.2 \%$ of the calls. Information about the response time of the code blue team is shown in Table 3. 


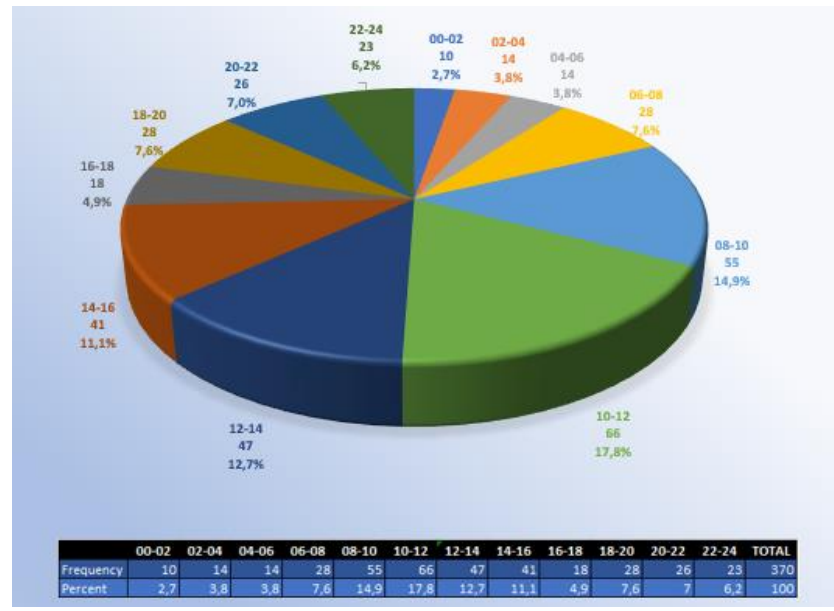

Table 3. Information about The Response Time of The Code Blue Team

\begin{tabular}{|l|c|}
\hline Arrival Time (min) & $2.63 \pm 0.1$ \\
\hline Team Arrival on Time Status & $\mathbf{n}=\mathbf{3 7 0}$ \\
\hline The Team Arrived On Time (\%) & $308(83.3)$ \\
\hline Device Error (\%) & $23(6.2)$ \\
\hline $\begin{array}{l}\text { The team arrived on time but made it late to } \\
\text { end the call (\%) }\end{array}$ & $27(7.3)$ \\
\hline Team Arrived Late (\%) & $12(3.2)$ \\
\hline Total (\%) & $370(100)$ \\
\hline
\end{tabular}

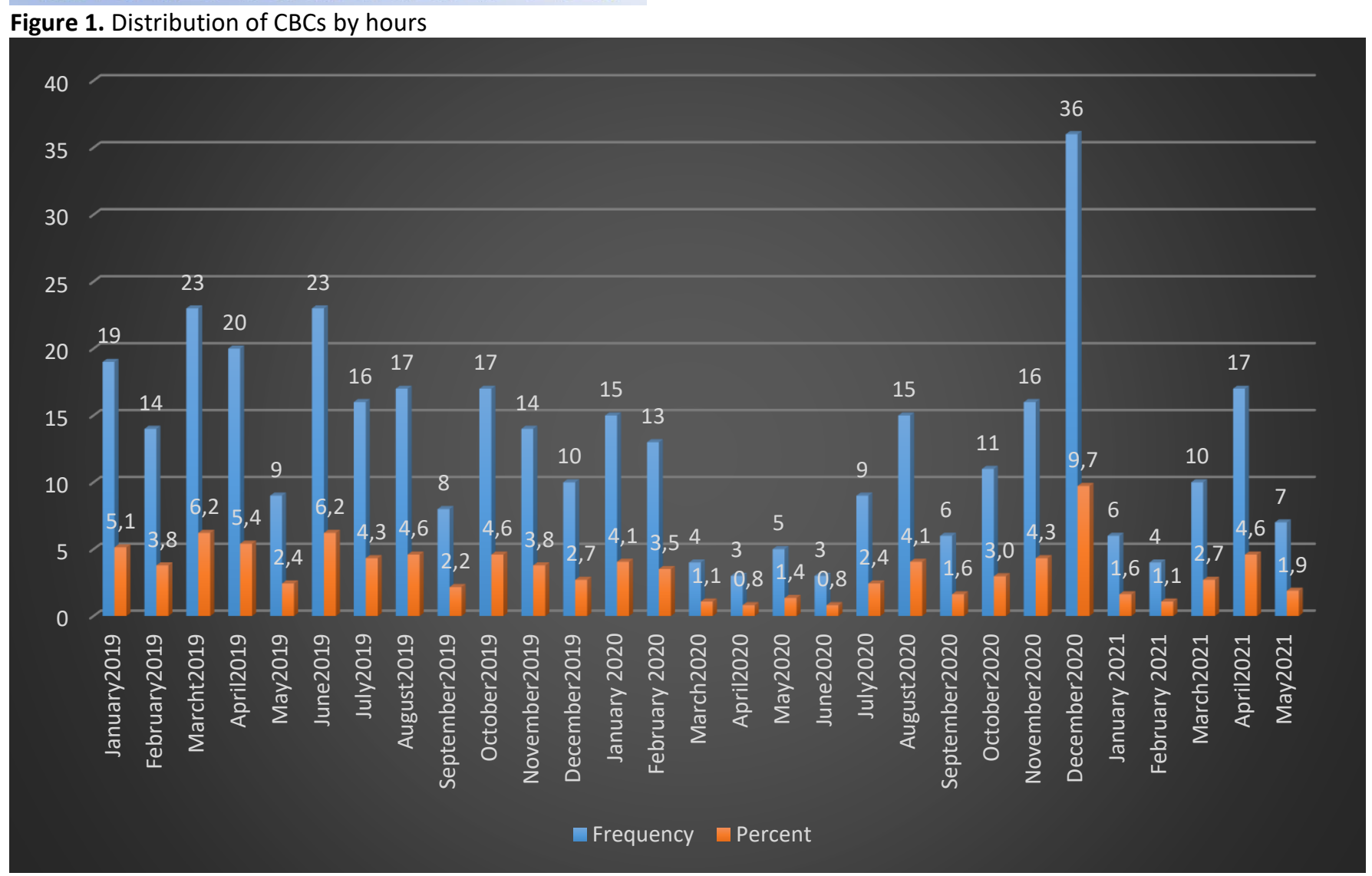

Figure 2. Distribution of CBCs by month

When CBCs were compared before and after the pandemic, a significant difference was found in terms of age $(p=0.017)$, gender $(p=0.03)$, defibrillation $(p=0.02)$, outcome $(p=0.001)$, team response time $(p=0.001)$ and prolonged call rates $(p=0.006)$. The comparison of CBCs before and after the Covid-19 pandemic is shown in Table 4.

The most common inpatient diagnoses for which code blue call was made before the pandemic were malignancy with $38.4 \%$ and CVE with $15.2 \%$, whereas the most common diagnoses after the pandemic were COVID-19 with $85.2 \%$ and malignancy with $4.8 \%$. The comparison of inpatient diagnoses with code blue call before and after the pandemic is shown in Table 5.

When we look at the places where $\mathrm{CBCs}$ was given, the most common ones were $32.1 \%$ polyclinics, $23.9 \%$ palliative care services before the pandemic, while $64.2 \%$ pandemic services and $23 \%$ polyclinics after the pandemic. The places where CBCs were made are shown in Table 6.

When the reasons for code blue calls were examined, it $s$ seen that the most common reason was cardiopulmonary ar- 
rest $(48.6 \%)$ followed by syncope $(21.6 \%)$ before the pandemic, while the most common reason was cardiopulmonary arrest $(48.6 \%)$ followed by poor general medical condition (16.9\%) after the pandemic. The reasons for CBCs are shown in Table 7.

\section{Discussion}

The findings of the present study showed that significant changes occurred in $\mathrm{CBCs}$ during the Covid-19 pandemic compared to the pre-pandemic period. $60 \%$ of the calls in our study belong to the pre-pandemic period. Compared to the pre-pandemic period, the mean age of code blue patients, male patient rate, transfer rate to the ICU, response time of the code blue team and prolonged call rates significantly increased during the pandemic. The rates of patients who underwent defibrillation decreased significantly during the pandemic. In addition, while malignancy was the most common inpatient diagnosis for CBC before the pandemic, COVID-19 was the most common diagnosis for $\mathrm{CBC}$ after the pandemic. While most $\mathrm{CBCs}$ were made from polyclinics before the pandemic, most $C B C s$ were made from Covid-19 services after the pandemic. When the reasons for $\mathrm{CBC}$ s were examined, there was no significant difference between cardiopulmonary arrest rates before and after the pandemic. To the best of our knowledge, this is the first study to compare CBCs and their outcomes before and after the pandemic.

During the pandemic, there have been many changes in Turkey and in our hospital. At certain times, outpatient services and elective surgeries were stopped, and many services and ICUs were reserved for COVID-19 patients. During this period, patients applications to the hospital were postponed except for urgent applications. In previous studies, it was reported that COVID-19 infection is more common in men and the prognosis worsens with increasing age $(12,13)$. In a previous study, it was reported that there was a significant increase in out-of-hospital arrests and deaths due to the pandemic in 2020 compared to 2019 (14). In another review, it was reported that return to spontaneous circulation and discharge from the hospital after cardiac arrest, CPR applications by witnesses in witnessed arrests decreased significantly during the pandemic, and ambulance response times to emergency calls increased (15). In addition, previous studies reported that the COVID-19 pandemic increases stress, depression and anxiety in healthcare professionals and has negative effects on mental health $(16,17)$. We believe that these and similar effects of the COVID-19 pandemic on the health system, patient behaviors and health personnel led to the results obtained in the present study.

According to the guideline prepared by The American Heart Association, it is reported that a response time of less than 2 minutes to cardiac arrest and giving the first electric shock significantly increases survival (3). When we look at the studies conducted in Turkey, it is seen that the average response time to CBCs was above the 3 minute target before 2010, and this value dropped below 3 minutes after 2010 (1-4, 18-20). In addition, according to the code blue regulation in Turkey, the target response time to code blue is less than 3 minutes (5).

Table 4. Pre-Pandemic-Pandemic Period Comparison of CBCs

\begin{tabular}{|c|c|c|c|}
\hline & $\begin{array}{c}\text { Before } \\
\text { Pandemic } \\
\text { ( } n=222 \text { ) }\end{array}$ & $\begin{array}{l}\text { Pandemic Pe- } \\
\text { riod }(n=148)\end{array}$ & $\begin{array}{c}\mathbf{P} \\
\text { Values }\end{array}$ \\
\hline Age & $61.50 \pm 21.74$ & $66.65 \pm 17.76$ & 0.017 \\
\hline \multicolumn{4}{|l|}{ Gender } \\
\hline Female (\%) & $112(50.5)$ & $58(39.2)$ & 0.03 \\
\hline \multicolumn{4}{|l|}{ Working Status } \\
\hline Overtime. (\%) & $131(59)$ & 75 (50.7) & \multirow[t]{2}{*}{0.11} \\
\hline Non-Overtime (\%) & $91(41)$ & $73(49.3)$ & \\
\hline \multicolumn{4}{|l|}{ Call Suitability } \\
\hline Appropriate Call (\%) & $106(47.7)$ & $74(50)$ & \multirow[t]{2}{*}{0.49} \\
\hline Inappropriate Call (\%) & $116(52.3)$ & $74(50)$ & \\
\hline Intubation (\%) & $105(47.3)$ & 69 (46.6) & 0.89 \\
\hline CPR $^{*}(\%)$ & $108(48.6)$ & $72(48.6)$ & 0.92 \\
\hline Defibrillation (\%) & $7(3.15)$ & $0(0)$ & 0.02 \\
\hline \multicolumn{4}{|l|}{ Result } \\
\hline Exitus (\%) & 70 (31.5) & $42(28.4)$ & \multirow{4}{*}{0.001} \\
\hline $\begin{array}{l}\text { Transfer to Intensive } \\
\text { Care Unit (\%) }\end{array}$ & $40(18)$ & $48(32.4)$ & \\
\hline $\begin{array}{l}\text { Transfer to Emergency } \\
\text { Room (\%) }\end{array}$ & $93(41.9)$ & $41(27.7)$ & \\
\hline $\begin{array}{l}\text { Follow-up in the Inpati- } \\
\text { ent Service }(\%)\end{array}$ & $19(8.6)$ & $17(11.5)$ & \\
\hline Team Arrival Time & $2.37 \pm 1.01$ & $2.99 \pm 1.68$ & 0.001 \\
\hline $\begin{array}{l}\text { Is Spontaneous Circula- } \\
\text { tion Provided? }(\%)\end{array}$ & $\begin{array}{l}\text { (CPR:108) } \\
35(32.4)\end{array}$ & $\begin{array}{l}\text { (CPR:72) } \\
33(45.8)\end{array}$ & 0.26 \\
\hline Prolonged Call (\%) & $28(12.6)$ & $34(23)$ & 0.006 \\
\hline Prolonged Call Reason & $\mathrm{n}: 28$ & $\mathrm{n}: \mathbf{3 4}$ & \\
\hline Device Error (\%) & $8(28.6)$ & $15(44.1)$ & \multirow{3}{*}{0.44} \\
\hline Team Arrived Late (\%) & $6(21.4)$ & $6(17.6)$ & \\
\hline Termination Error (\%) & $14(50)$ & $13(38.3)$ & \\
\hline
\end{tabular}

"CPR: Cardiopulmonary Resuscitation

In the present study, the average response time of the $\mathrm{CBC}$ team was $2.63 \pm 0.1$. In the present study, response time was above 3 minutes in only $3.2 \%$ of the cases. These times can be further reduced with trainings.

In previous research, it was reported that majority of CBCs are made for male patients (2-4). In the present study, it was found that $54.1 \%$ of CBCs were made for male patients, which is consistent with the literature.

In some studies in the literature, it was reported that CBCs were most frequently made from internal medicine service (2). In other studies, it was reported that CBCs were most frequently made from internal medicine intensive care unit and emergency service $(3,4)$. In the present study, CBCs were most frequently made from outpatient clinics with $28.6 \%$, followed by Covid-19 service with $25.7 \%$ and palliative care service with $15.9 \%$. These findings can be explained by the physical conditions of our hospital and the effects of the COVID-19 pandemic.

Previous studies reported that CBCs are mostly made outside of work hours $(3,4)$. In contrast, most calls $(55.7 \%)$ were made during working hours in the present study. We think that this difference is due to the physical conditions of our hospital and the high rate of calls from outpatient clinics. 
Table 5. Pre-Pandemic-Pandemic Period Hospitalization Diagnoses of Inpatients Given Code Blue Call

\begin{tabular}{|l|c|c|}
\hline & $\begin{array}{l}\text { Before Pan- } \\
\text { demic }\end{array}$ & $\begin{array}{l}\text { Pandemic Pe- } \\
\text { riod }\end{array}$ \\
\hline Hospitalization Diagnosis & $\mathbf{n = 1 2 5}$ & $\mathbf{n = 1 0 8}$ \\
\hline COVID-19 (\%) & $0(0)$ & $92(85.2)$ \\
\hline Acute Kidney Failure (\%) & $3(2.4)$ & $1(0.9)$ \\
\hline Chronic renal failure (\%) & $7(5.6)$ & $1(0.9)$ \\
\hline Diabetes Mellitus (\%) & $3(2.4)$ & $1(0.9)$ \\
\hline Congestive Heart Failure (\%) & $4(3.2)$ & $1(0.9)$ \\
\hline Cerebrovascular Event (\%) & $19(15.2)$ & $2(1.7)$ \\
\hline Malignancy (\%) & $48(38.4)$ & $5(4.8)$ \\
\hline Orthopedic Surgery (\%) & $6(4.8)$ & $3(2.9)$ \\
\hline Hypertension (\%) & $2(1.6)$ & $1(0.9)$ \\
\hline Epilepsy (\%) & $1(0.8)$ & $1(0.9)$ \\
\hline Pneumonia (\%) & $8(6.4)$ & $0(0)$ \\
\hline Sepsis (\%) & $7(5.6)$ & $0(0)$ \\
\hline Urinary System Infection (\%) & $4(3.2)$ & $0(0)$ \\
\hline Acute Appendicitis (\%) & $2(1.6)$ & $0(0)$ \\
\hline $\begin{array}{l}\text { Pulmonary Thromboembolism } \\
\text { (\%) }\end{array}$ & $1(0.8)$ & $0(0)$ \\
\hline $\begin{array}{l}\text { Chronic Obstructive Pulmonary } \\
\text { Disease (\%) }\end{array}$ & $3(2.4)$ & $0(0)$ \\
\hline Ileus (\%) & $4(3.2)$ & $0(0)$ \\
\hline Gastroenteritis (\%) & $2(1.6)$ & $0(0)$ \\
\hline Nephrolithiasis (\%) & $1(0.8)$ & $0(0)$ \\
\hline
\end{tabular}

Table 6. Comparison of Code Blue Call Places Pre-PandemicPandemic Period

\begin{tabular}{|l|l|l|}
\hline & $\begin{array}{l}\text { Before Pan- } \\
\text { demic }\end{array}$ & $\begin{array}{l}\text { Pandemic } \\
\text { Period }\end{array}$ \\
\hline Call Place & $\mathbf{n}=\mathbf{2 2 2}$ & $\mathbf{n = 1 4 8}$ \\
\hline Polyclinics (\%) & $\mathbf{7 2 ( 3 2 . 1 )}$ & $34(23)$ \\
\hline Pandemic Service (\%) & $0(0)$ & $95(64.2)$ \\
\hline Radiology/Imaging (\%) & $13(5.7)$ & $3(2)$ \\
\hline Laboratory (\%) & $10(4.6)$ & $0(0)$ \\
\hline Dialysis Unit (\%) & $3(1.4)$ & $1(0.7)$ \\
\hline Internal Medicine Service (\%) & $22(9.9)$ & $3(2)$ \\
\hline Infectious Diseases Service (\%) & $12(5.4)$ & $0(0)$ \\
\hline Orthopedic Service (\%) & $6(2.7)$ & $3(2)$ \\
\hline General Surgery Service (\%) & $10(4.6)$ & $2(1.4)$ \\
\hline Neurology Service (\%) & $15(6.8)$ & $1(0.7)$ \\
\hline Palliative Care Service (\%) & $53(23.9)$ & $6(4)$ \\
\hline Cardiology Service (\%) & $3(1.4)$ & $0(0)$ \\
\hline Urology Service (\%) & $1(0.5)$ & $0(0)$ \\
\hline Neurosurgery Service (\%) & $1(0.5)$ & $0(0)$ \\
\hline Chest Diseases Service (\%) & $1(0.5)$ & $0(0)$ \\
\hline
\end{tabular}

In previous research, it was reported that $59.5 \%$ of $\mathrm{CBCs}$ were made due to cardiopulmonary arrest (4). In another study, CPR was required in $29 \%$ of CBC patients (20). The reason for code blue was cardiopulmonary arrest in $48.6 \%$ of the patients in our study and CPR was needed. Our findings are consistent with the literature. However, unnecessary calls reduce the motivation and energy of the code blue team. This situation can be corrected with effective training for all healthcare professionals.
In a previous study, it was reported that CPR was ineffective in $80 \%$ of CBCs requiring CPR (20). Rate of successful CPR in the present study was $37.8 \%$.

In a previous study, it was reported that $23.2 \%$ of CBCs resulted in exitus (20). In another study, exitus rate was $39.1 \%$ (19). CBC outcomes in the present study were similar to the literature and rate of exitus was $30.3 \%$.

Table 7. Comparison of the Reasons for Calling for Code Blue between Pre-Pandemic and Pandemic Period

\begin{tabular}{|l|l|l|}
\hline & $\begin{array}{c}\text { Before } \\
\text { Pandemic }\end{array}$ & $\begin{array}{c}\text { Pandemic } \\
\text { Period }\end{array}$ \\
\hline Reason for Call & $\mathbf{n = 2 2 2}$ & $\mathbf{n = 1 4 8}$ \\
\hline Cardiopulmonary Arrest (\%) & $108(48.6)$ & $72(48.6)$ \\
\hline Syncope (\%) & $48(21.6)$ & $14(9.4)$ \\
\hline Seizure (\%) & $12(5.4)$ & $3(2)$ \\
\hline Anxiety/Conversion (\%) & $9(4)$ & $10(6.8)$ \\
\hline Hypotensive Attack (\%) & $33(14.7)$ & $15(10.1)$ \\
\hline Consciousness Change (\%) & $3(1.4)$ & $4(2.7)$ \\
\hline General Condition Disorder (\%) & $7(3.2)$ & $25(16.9)$ \\
\hline Chest Pain (\%) & $0(0)$ & $1(0.7)$ \\
\hline Anaphylaxis (\%) & $1(0.5)$ & $1(0.7)$ \\
\hline Respiratory Distress (\%) & $3(1.4)$ & 0 \\
\hline Arrhythmia (\%) & $1(0.5)$ & $1(0.7)$ \\
\hline
\end{tabular}

\section{Conclusion}

The findings of this study showed that when compared to the pre-pandemic period, the average age of code blue patients, male patient rate, transfer rate to the ICU, the response time of the code blue team and the prolonged call rates increased significantly during the COVID-19 pandemic. The rates of patients who underwent defibrillation decreased significantly during the COVID-19 pandemic. In addition, the number of code blue calls requiring CPR was lower. The response time of the code blue team and successful CPR rates are similar to the literature. With continuous and effective training, $C B C$ performance can be further increased.

\section{Limitations}

The most important limitation of this study was its retrospective design and the fact that it was carried out in a single center. The findings of the present study can be supported by future prospective and multicenter studies.

Ethical Approval: Ethical permission for the study was obtained by the deci-sion of the Health Sciences University Samsun Training and Research Hospital Non-Interventional Clinical Research Ethics Committee dated 05.05.2021 and numbered 2021/9/13.

\section{Author Contributions:}

Concept: M.O., M.B.T

Literature Review: M.O.

Design : M.O., M.B.T

Data acquisition: M.O.

Analysis and interpretation: M.O.

Writing manuscript: M.O.

Critical revision of manuscript: M.B.T. 
Conflict of Interest: The authors have no conflicts of interest to declare.

Financial Disclosure: Authors declared no financial support.

\section{References}

1. Murat E, Toprak S, Doğan DB, Mordoğan F. The Code Blue Experiences: Gains, Problems and Troubleshooting. Medicine Science. 2014;3(1):1002-12

2. Esen O, Esen HK, Öncül S, Gaygusuz EA, Yılmaz M, Bayram E. Code Blue Practices and Evaluation of Results in a Training and Research Hospital. J Kartal TR .2016;27(1):57-61

3. Özmete Ö. Results of a blue code implementation at a university hospital. Cukurova Med J 2017;42(3):446-50

4. Özütürk B, Muhammedoğlu N, Dal E, Çalışkan B. Evaluation of Code Blue Implementation Outcomes. The Medical Bulletin of Haseki. 2015; 53:204-8

5. Resmi Gazete (2011), Sağlık Bakanlığı, Hasta ve Çalışan Güvenliğinin Sağlanmasına Dair Yönetmelik, R.G: 06/04/2011, sayı: 27897

6. Bingol Tanriverdi T, Patmano G, Bozkurt FT, Kaya BC, Tercan M. Prognostic value of $C$-reactive protein to albumin ratio in patients resuscitated from out-of-hospital cardiac arrest. Int J Clin Pract. 2021;75(7):e14227.

7. Khan FA, Lyu T, Lee EK, Dhanvijay S, Kansal A, Kansal MG, et al. Impact of implementing novel automated code blue activation system on in-hospital cardiac arrest: A single center study. Resuscitation. 2020 Dec;157:149-55.

8. Andersen LW, Holmberg MJ, Berg KM, Donnino MW, Granfeldt A. In-Hospital Cardiac Arrest: A Review. JAMA. 2019 Mar 26;321(12):1200-10.

9. Ocak M, Çetinkaya H, Kesim H. A Case of High Dose Metoprolol Poisoning; Case Report and Literature Review. International Journal of Current Medical and Biological Science. 2021;1(1):1215

10. Spitzer CR, Evans K, Buehler J, Ali NA, Besecker BY. Code blue pit crew model: A novel approach to in-hospital cardiac arrest resuscitation. Resuscitation. 2019 Oct;143:158-64.

11. Ornato JP, Peberdy MA, Reid RD, Feeser VR, Dhindsa HS; NRCPR Investigators. Impact of resuscitation system errors on survival from in-hospital cardiac arrest. Resuscitation. 2012 Jan;83(1):63-9.

12. Simsek Yurt N, Ocak M, Yurt YC. Epidemiological and clinical characteristics of 3334 cases with prediagnosis coronavirus disease - 2019 (COVID-19) in Turkey. Int J Clin Pract. 2021 Jun 26:e14496.

13. Li LQ, Huang $T$, Wang $Y Q$, Wang $Z P$, Liang $Y$, Huang $T B$, et al. COVID-19 patients' clinical characteristics, discharge rate, and fatality rate of meta-analysis. J Med Virol. 2020 Jun;92(6):57783.

14. Baldi E, Sechi GM, Mare C, Canevari F, Brancaglione A, Primi R, et al. COVID-19 kills at home: the close relationship between the epidemic and the increase of out-of-hospital cardiac arrests. Eur Heart J. 2020 Jun 1;41(32):3045-54.

15. Scquizzato $T$, Landoni G, Paoli A, Lembo R, Fominskiy E, Kuzovlev A, et al. Effects of COVID-19 pandemic on out-of-hospital cardiac arrests: A systematic review. Resuscitation. 2020 Dec;157:241-7.

16. Salari N, Hosseinian-Far A, Jalali R, Vaisi-Raygani A, Rasoulpoor $S$, Mohammadi $M$, et al. Prevalence of stress, anxiety, depression among the general population during the COVID-19 pandemic: a systematic review and meta-analysis. Global Health. 2020 Jul 6;16(1):57.
17. Havlioğlu S, Demir HA. Determining the Anxiety Levels of Emergency Service Employees' Working During The Covid-19 Pandemic. Journal of Harran University Medical Fakulty. 2020;17(2):251-5

18. Canural R, Gökalp N, Yıldırım K, Şahin M, Korkmaz A, Şahin N, et al. Sağlık Hizmetlerinde Hasta Güvenliği: Mavi Kod Uygulaması Uluslararası Sağlıkta Performans ve Kalite Kongresi Bildirileri Kitabı. Sağlık Bakanlığı, Ankara, 2009;772(2):525-40.

19. Mehel D, Şen M, Sakarya Ö, Dinç S. Hasta ve Çalışan Güvenliğinde Mavi Kod Uygulaması. II. Uluslararası Sağlıkta Performans ve Kalite Kongresi Bildirileri Kitabı. Sağlık Bakanlığı, Ankara, 2010; 772 (2): 614-6.

20. Türkyılmaz EU, Güzey NA. Retrospectıve Analyse Of Code Blue Records In A Women's Health Center. The Journal of Gynecology - Obstetrics and Neonatology.2019;16(2):89-92 